\title{
Highlights of the 2018 Chinese hypertension guidelines
}

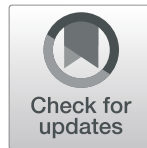

Jing Liu

\begin{abstract}
Background: Blood pressure (BP) are uncontrolled in over 80\% hypertensive population in China, indicating a compelling need for a pragmatic hypertension management strategy. The 2018 Chinese hypertension guidelines issued in 2019, after 3 years revision. During the periods, the latest United States (US) and European guidelines successively published, bringing new thoughts, wisdoms and schemes on hypertension management. This review aims to summarize the highlights of the new Chinese guidelines.

Main text: Despite the fact that the 2017 US hypertension guidelines changed hypertension definition from $\geq 140 / 90 \mathrm{mmHg}$ to $130 / 80 \mathrm{mmHg}$, the Chinese hypertension guidelines did not follow suit, and maintained 140/ $90 \mathrm{mmHg}$ as the cut-point of for diagnosis of hypertension. A combined, cardiovascular risks and BP levels-based antihypertensive treatment algorithm was introduced. Five classes of antihypertensive drugs, including $\beta$-blockers were recommended as initiation and maintenance of BP-lowering therapy. Initiating combination therapy, including single pill combination (SPC) was indicated in high-risk patients or those with grade 2 or 3 hypertension. For those with grade 1 hypertension ( $\mathrm{BP} \geq 140 / 90 \mathrm{mmHg}$ ), an initial low-dose antihypertensive drugs combination treatment could be considered.

Conclusions: China has never stopped exploring the best strategy for improving hypertension control. Based on clinical evidence and expertise, the newest Chinese guidelines and expert consensus will be of help in guiding physicians and practitioners to provide better management of hypertension in China.
\end{abstract}

Keywords: Chinese, Hypertension, Guidelines

\section{Background}

After 3 years and more than 30 symposiums on revision, the final English version of the 2018 Chinese Guidelines for Prevention and Treatment of Hypertension (Revised Edition) was officially published in March, 2019 [1]. During these periods, the United States (US) and Europe successively updated the hypertension guidelines $[2,3]$. The 2018 Chinese hypertension guidelines revision committee borrowed experience from colleagues of the international societies, combined with expertise in clinical practice and evidence accumulated from population studies and clinical trials on blood pressure (BP)-lowering therapy in China

\section{Correspondence: heartcenter@163.com}

Department of Cardiology, Peking University People's Hospital, Beijing 100044, China and worldwide, and formed Chinese characteristic guidelines for management of hypertension.

Hypertension is the leading risk factors of mortality in China, accounted for 2.54 million deaths in 2017 and most were due to cardiovascular diseases [4]. It was estimated about 23.2\% (244.5 million) Chinese adults had hypertension, the awareness and treatment rate are 46.9 and $40.7 \%$ respectively, and only $15.3 \%$ was controlled [5]. Over 20 years, Chinese Hypertension League (CHL) has issued 4 editions of national hypertension guidelines since 1999, with the endorsement of Chinese Society of Cardiology (CSC) and other organizations. In past, the former three editions have played important role in guiding clinical practice and improving hypertension management. The 2018 Chinese hypertension guidelines

(c) The Author(s). 2020 Open Access This article is licensed under a Creative Commons Attribution 4.0 International License, which permits use, sharing, adaptation, distribution and reproduction in any medium or format, as long as you give appropriate credit to the original author(s) and the source, provide a link to the Creative Commons licence, and indicate if changes were made. The images or other third party material in this article are included in the article's Creative Commons licence, unless indicated otherwise in a credit line to the material. If material is not included in the article's Creative Commons licence and your intended use is not permitted by statutory regulation or exceeds the permitted use, you will need to obtain permission directly from the copyright holder. To view a copy of this licence, visit http://creativecommons.org/licenses/by/4.0/ The Creative Commons Public Domain Dedication waiver (http://creativecommons.org/publicdomain/zero/1.0/) applies to the data made available in this article, unless otherwise stated in a credit line to the data. 
will provide millions of doctors in China with a clear and accessible roadmap for hypertension control.

What are the key points of the 2018 Chinese hypertension guidelines?

\section{Main text}

\section{Blood pressure measurement}

The 2018 Chinese hypertension guidelines highlight that accurate BP measurement is the fundamental for assessing BP levels, establishing diagnosis of hypertension and evaluating the efficacy of antihypertensive treatment.

Clinic (Office) BP measurement (CBPM) currently remains the common method measuring BP in outpatient clinics in China. Meanwhile out-of-office BP measurements, including ambulatory BP monitoring (ABPM) or home BP monitoring (HBPM), are advocated to confirm the diagnosis of hypertension, identify white-coat hypertension or masked hypertension, evaluate BP variation, and assess antihypertensive efficacy, if available. In addition, HBPM can improve the adherence of antihypertensive treatment, and might be of help improving $\mathrm{BP}$ control. With the development of telemetry technology and equipment, internet-based BP remote monitoring is expected to become a new model for BP management in the future.

\section{Definition and classification of hypertension}

2017 US hypertension guidelines changed the definition of hypertension from the general accepted cut-point of $140 / 90 \mathrm{mmHg}$ to $130 / 80 \mathrm{mmHg}$ [2], arousing controversy worldwide.

Given that the awareness, treatment and control rate of hypertension in China are still low, changing threshold for diagnosis of hypertension to $\geq 130 / 80 \mathrm{mmHg}$ will dramatically increase the volume of hypertensive patients, including those need to treat, which will inevitably bring huge disease burden and much more medical expenditure [6]. On the other hand, changing hypertension definition to $\geq 130 / 80 \mathrm{mmHg}$ is not endorsed by most of international hypertension societies, the later released 2018 European hypertension guidelines refused to make any alternation on this issue. Therefore, the 2018 Chinese hypertension guidelines did not follow suit with the US guidelines and maintained the current cut-point of $\geq 140 / 90 \mathrm{mmHg}$ for hypertension diagnosis. The latest issued Korean and Japanese hypertension guidelines also maintained 140/90 $\mathrm{mmHg}$ as the definition criteria of hypertension [7-10].

BP classification and comparison between Chinese and international hypertension guidelines could be seen as following (Table 1).

\section{Cardiovascular risk stratification}

Cardiovascular (CV) risk stratification in hypertensive patients is the basis of initiating antihypertensive therapy and the determinants of establishing appropriate BP targets and antihypertensive treatment strategies.

In the 2018 Chinese hypertension guidelines, hypertensive patients are classified to one of the following CV risk strata, from low risk, moderate risk, high risk to very high risk (Table 2), referring to the $\mathrm{BP}$ levels and $\mathrm{CV}$ risk factors, target organ damages or complications. Similar with 2018 European hypertension guidelines [3], BP range between 130 and $139 / 85-89 \mathrm{mmHg}$ is also added in the category for $\mathrm{CV}$ risk evaluation.

In addition to the traditional CV risk factors, hyperhomocysteinemia is recognized as a meaningful predictor for stroke, a highly prevalent complication of hypertension in Chinese population, based on the evidence from cohort study and Chinese Stroke Primary Prevention Trial (CSPPT) [11, 12], with a modified cut-point of $\geq 15 \mathrm{umol} / \mathrm{L}$ (Table 3). This is unique, and not seen in the Korean and Japanese hypertension guidelines [7-10].

Table 1 BP categories in Chinese, Korean, Japanese, US and European hypertension guidelines

\begin{tabular}{|c|c|c|c|c|c|}
\hline $\begin{array}{l}\text { BP category } \\
(\mathrm{mmHg})\end{array}$ & CHL $2018[1]$ & KSH 2018 [7-9] & JSH 2019 [10] & AHA/ACC 2017 [2] & ESC/ESH 2018 [3] \\
\hline $\mathrm{SBP}<120$ and $\mathrm{DBP}<80$ & Normal & Normal & Normal & Normal & Optimal \\
\hline SBP: $120-129$ and $D B P<80$ & High normal & Elevated & High normal & Elevated & Normal ${ }^{\mathrm{a}}$ \\
\hline SBP: 130-139 and (or) DBP: 80-89 & & Prehypertension & Elevated & Grade 1 hypertension & High normal ${ }^{b}$ \\
\hline SBP: 140-159 and (or) DBP: 90-99 & $\begin{array}{l}\text { Grade } 1 \\
\text { hypertension }\end{array}$ & Grade 1 hypertension & Grade 1 hypertension & Grade 2 hypertension & Grade 1 hypertension \\
\hline $\begin{array}{l}\text { SBP: } 160-179 \text { and (or) DBP: } \\
100-109\end{array}$ & $\begin{array}{l}\text { Grade } 2 \\
\text { hypertension }\end{array}$ & Grade 2 hypertension & Grade 2 hypertension & & Grade 2 hypertension \\
\hline $\mathrm{SBP} \geq 180$ and (or) $\mathrm{DBP} \geq 110$ & $\begin{array}{l}\text { Grade } 3 \\
\text { hypertension }\end{array}$ & & Grade 3 hypertension & & Grade 3 hypertension \\
\hline $\mathrm{SBP} \geq 140$ and $\mathrm{DBP}<90$ & $\mathrm{ISH}$ & $\mathrm{ISH}$ & $\mathrm{ISH}$ & NA & $\mathrm{ISH}$ \\
\hline
\end{tabular}

ACC American College of Cardiology, AHA American Heart Association, BP blood pressure, CHL Chinese Hypertension League, DBP diastolic BP, ESC European Society of Cardiology, ESH European Society of Hypertension, ISH isolated systolic hypertension, JSH Japanese Society of Hypertension, KSH Korean Society of Hypertension, NA not available, SBP systolic BP.

a DBP: $80-84 \mathrm{mmHg}$

b DBP: $85-89 \mathrm{mmHg}$. 
Table 2 Cardiovascular risk stratification in patients with elevated BP

\begin{tabular}{|c|c|c|c|c|}
\hline \multirow[b]{2}{*}{ Other risk factors and medical history } & \multicolumn{4}{|c|}{$\mathrm{BP}, \mathrm{mmHg}$} \\
\hline & $\begin{array}{c}\text { SBP 130-139 and (or) } \\
\text { DBP 85-89 }\end{array}$ & $\begin{array}{l}\text { SBP 140-159 and (or) } \\
\text { DBP 90-99 }\end{array}$ & $\begin{array}{l}\text { SBP 160-179 and (or) } \\
\text { DBP 100-109 }\end{array}$ & $\begin{array}{c}\mathrm{SBP} \geq 180 \text { and }(\mathrm{or}) \\
\mathrm{DBP} \geq 110\end{array}$ \\
\hline No other risk factors & & Low risk & Moderate risk & High risk \\
\hline $1-2$ risk factors & Low risk & Moderate risk & Moderate to high risk & Very high risk \\
\hline $\begin{array}{l}\geq 3 \text { risk factors, TOD or CKD grade } 3 \text { or } \\
\text { diabetes mellitus without organ damage }\end{array}$ & Moderate/high risk & High risk & High risk & Very high risk \\
\hline $\begin{array}{l}\text { Clinical complications, or CKD grade } \geq 4 \text {, } \\
\text { or diabetes mellitus with organ damage }\end{array}$ & High/very high risk & Very high risk & Very high risk & Very high risk \\
\hline
\end{tabular}

BP: blood pressure; CKD: chronic kidney disease; DBP. diastolic blood pressure; SBP: systolic blood pressure; TOD: target organ damage.

\section{Treatment of hypertension}

The 2018 Chinese hypertension guidelines recommend a treatment target of office BP (OBP) $<140 / 90 \mathrm{mmHg}$ in general hypertensive patients, and further $<130 / 80$ $\mathrm{mmHg}$, if tolerated or in high-risk category. In older patients $(65-79$ years), it is recommended that systolic BP should be targeted to $<150 \mathrm{mmHg}$, and further $<140$ $\mathrm{mmHg}$, if tolerated. In elderly patients aged 80 years or over, a systolic BP target of $<150 \mathrm{mmHg}$ is recommended.

BP targets in special population, such as diabetes mellitus (DM), chronic kidney disease (CKD) and poststroke secondary prevention are also recommended in guidelines. A comparison of BP targets in Chinese and international guidelines could be seen as following (Table 4).

Antihypertensive treatment should be initiated on basis of CV risk assessment, combined with the BP levels (Fig. 1). Briefly, Patients with high or very high $\mathrm{CV}$ risk should initiate antihypertensive drug therapy immediately. Patients with low to moderate CV risk should also start antihypertensive agent treatment after several weeks' lifestyle modification, alongside monitoring and follow-up.

Unlike 2017 US guidelines of kicking $\beta$-blockers off the first-line of antihypertensive therapy [2], the 2018 Chinese hypertension guidelines insist on recommending that all five classes of antihypertensive drugs, including calcium channel blockers (CCBs), angiotensin-converting enzyme inhibitors (ACEIs), angiotensin II receptor blockers $(\mathrm{ARBs})$, diuretics and $\beta$-blockers, are suitable for the initiation and maintenance of BP-lowering therapy. This recommendation is in line with 2018 European hypertension guidelines and later published 2018 Korean guidelines [3, 7-9], while 2019 Japanese guidelines is in step with the US guidelines and recommend ACEIs、ARBs、CCBs and diuretics as the first-line antihypertensive agents in patients without compelling indications [10].

Initiating combination therapy, including single pill combination (SPC) is indicated in high-risk hypertensive patients or those $\mathrm{BP} \geq 160 / 100 \mathrm{mmHg}$ or $20 / 10 \mathrm{mmHg}$ above the BP target. For those $\mathrm{BP} \geq 140 / 90 \mathrm{mmHg}$, an initial low-dose antihypertensive drugs combination therapy could also be considered. This is a more aggressive recommendation than ever, as the evidence from

Table 3 Factors influencing cardiovascular prognosis in hypertensive patients

\begin{tabular}{|c|c|c|}
\hline Cardiovascular risk factors & TOD & Concomitant clinical diseases \\
\hline $\begin{array}{l}\text { - Hypertension (Grade } 1-3 \text { ) } \\
\text { - Man > } 55 \text { years } \\
\text { - Woman }>65 \text { years } \\
\text { - Smoking or passive smoking } \\
\text { - Impaired glucose tolerance (7.8-11.0 } \\
\text { mmol/L for 2-h blood glucose) and/or } \\
\text { impaired fasting glucose (6.1-6.9 mmol/L) } \\
\text { - Dyslipidemia TC } \geq 5.2 \mathrm{mmol} / \mathrm{L}(200 \mathrm{mg} / \\
\mathrm{dL} \text { ) or LDL-C } \geq 3.4 \mathrm{mmol} / \mathrm{L}(130 \mathrm{mg} / \mathrm{dL}) \\
\text { or HDL-C }<1.0 \mathrm{mmol} / \mathrm{L}(40 \mathrm{mg} / \mathrm{dL}) \\
\text { - Family history of early onset } \\
\text { cardiovascular disease (onset of first- } \\
\text { degree relatives at age }<50 \text { years) } \\
\text { - Abdominal obesity (waist } \\
\text { circumference: Man } \geq 90 \mathrm{~cm}, \text { Woman } \\
\geq 85 \mathrm{~cm} \text { ) or obesity (BMI } \geq 28 \mathrm{~kg} / \mathrm{m} 2) \\
\text { - Hyperhomocysteinemia (> = } 15 \mathrm{mmol} / \mathrm{L})\end{array}$ & $\begin{array}{l}\text { - Left ventricular hypertrophy electrocardiogram: } \\
\text { Sokolow-Lyon voltage > } 3.8 \mathrm{mV} \text { or Cornell product } \\
>244 \mathrm{mV} \cdot \mathrm{ms} \text { Echocardiogram: LVMI (man } \geq 115 \mathrm{~g} / \\
\mathrm{m} 2 \text { woman } \geq 95 \mathrm{~g} / \mathrm{m} 2 \text { ) } \\
\text { - Carotid ultrasonography (IMT } \geq 0.9 \mathrm{~mm} \text { ) or } \\
\text { atherosclerotic plaque } \\
\text { - Carotid-femoral pulse wave velocity } \geq 12 \mathrm{~m} / \mathrm{s} \\
\text { (*optional) } \\
\text { - Ankle/Brachial index < } 0.9 \text { (*optional) }^{*} \text { - Reduced estimated glomerular filtration rate } \\
\text { (eGFR } 30-59 \mathrm{~mL} / \mathrm{min} \text { per } 1.73 \mathrm{~m} 2) \text { or slight increase } \\
\text { in serum creatinine: Man } 115-133 \mathrm{~mol} / \mathrm{L}(1.3-1.5 \\
\text { mg/dL), Woman } 107-124 \mathrm{~mol} / \mathrm{L}(1.2-1.4 \mathrm{mg} / \mathrm{dL}) \\
\text {-Microalbuminuria: } 30-300 \mathrm{mg} / 24 \mathrm{~h} \text { or albumin/ } \\
\text { creatinine ratio } \geq 30 \mathrm{mg} / \mathrm{g}(3.5 \mathrm{mg} / \mathrm{mmol})\end{array}$ & $\begin{array}{l}\text { - Cerebrovascular disease Cerebral hemorrhage } \\
\text { Ischemic stroke Transient ischemic attack } \\
\text { - Heart disease History of myocardial infarction } \\
\text { Angina pectoris Coronary revascularization } \\
\text { Congestive heart failure Atrial fibrillation } \\
\text { - Renal disease: Diabetic nephropathy Renal } \\
\text { dysfunction Including eGFR }<30 \mathrm{~mL} / \mathrm{min}^{*} 1.73 \mathrm{~m}^{2} \text {; } \\
\text { elevated serum creatinine: } \mathrm{man} \geq 133 \mathrm{umol} / \mathrm{L}(1.5 \\
\text { mg/dL), woman } \geq 124 \mathrm{umol} / \mathrm{L}(1.4 \mathrm{mg} / \mathrm{dL}) \text {; } \\
\text { proteinuria: } \geq 300 \mathrm{mg} / 24 \mathrm{~h}) \\
\text { - Peripheral vascular disease } \\
\text { - Advanced retinopathy: Hemorrhages or exudates } \\
\text { Papilloedema } \\
\text { - Diabetes mellitus Newly diagnosed: Fasting blood } \\
\text { glucose } \geq 7.0 \mathrm{mmol} / \mathrm{L}(126 \mathrm{mg} / \mathrm{dL}) ; \text { postprandial } \\
\text { blood glucose } \geq 11.1 \text { mmol/L ( } 200 \mathrm{mg} / \mathrm{dL}) \text { Treated } \\
\text { but not controlled: Glycated hemoglobin: } \\
\text { (HbA1c) } \geq 6.5 \%\end{array}$ \\
\hline
\end{tabular}

$B M I$ body mass index, eGFR estimated glomerular filtration rate, $H D L-C$ high-density lipoprotein, $I M T$ intima media thickness, $L D L-C$ low-density lipoprotein; $L V M I$ left ventricular mass index, TC total cholesterol, TOD Target organ damage. 
Table 4 BP targets in Chinese, Korean, Japanese, US and European hypertension guidelines

\begin{tabular}{|c|c|c|c|c|c|}
\hline & CHL 2018 [1] & KSH 2018 [7-9] & JSH 2019 [10] & AHA/ACC 2017 [2] & ESC/ESH 2018 [3] \\
\hline Young \& middle-aged adults & $<140 / 90 \mathrm{mmHg}^{\mathrm{a}}$ & $<140 / 90 \mathrm{mmHg}^{\mathrm{c}}$ & $<130 / 80 \mathrm{mmHg}$ & $<130 / 80 \mathrm{mmHg}$ & $120-130 / 70-79 \mathrm{mmHg}$ \\
\hline \multirow[t]{2}{*}{ Elderly } & $\begin{array}{l}65-79 y \\
<150 / 90 \mathrm{mmHg}^{\mathrm{b}}\end{array}$ & $\begin{array}{l}\geq 65 \mathrm{y} \\
<140 / 90 \mathrm{mmHg}\end{array}$ & $\begin{array}{l}\geq 75 \mathrm{y} \\
<140 / 90 \mathrm{mmHg}\end{array}$ & $\begin{array}{l}\geq 65 \mathrm{y} \\
<130 / 80 \mathrm{mmHg}\end{array}$ & $\begin{array}{l}65-79 y \\
130-139 / \\
70-79 \mathrm{mmHg}\end{array}$ \\
\hline & $\begin{array}{l}\geq 80 \mathrm{y} \\
<150 / 90 \mathrm{mmHg}\end{array}$ & & & & $\begin{array}{l}\geq 80 \mathrm{y} \\
130-139 / \\
70-79 \mathrm{mmHg}\end{array}$ \\
\hline DM & $<130 / 80 \mathrm{mmHg}$ & $<140 / 85 \mathrm{mmHg}^{\mathrm{c}}$ & $<130 / 80 \mathrm{mmHg}$ & $<130 / 80 \mathrm{mmHg}$ & $120-130 / 70-79 \mathrm{mmHg}^{\mathrm{f}}$ \\
\hline CKD without proteinuria & $<140 / 90 \mathrm{mmHg}$ & $<140 / 90 \mathrm{mmHg}$ & $<140 / 90 \mathrm{mmHg}$ & $<130 / 80 \mathrm{mmHg}$ & 130-139/70-79 mmHg \\
\hline CKD with proteinuria & $<130 / 80 \mathrm{mmHg}$ & $<130 / 80 \mathrm{mmHg}$ & $<130 / 80 \mathrm{mmHg}$ & $<130 / 80 \mathrm{mmHg}$ & 130-139/70-79 mmHg \\
\hline Secondary prevention of stroke & $<140 / 90 \mathrm{mmHg}$ & $<140 / 90 \mathrm{mmHg}^{\mathrm{d}}$ & $<130 / 80 \mathrm{mmHg}^{\mathrm{e}}$ & $<130 / 80 \mathrm{mmHg}$ & $120-130 / 70-79 \mathrm{mmHg}^{\mathrm{f}}$ \\
\hline$C A D$ & $<140 / 90 \mathrm{mmHg}^{\mathrm{a}}$ & $<130 / 80 \mathrm{mmHg}$ & $<130 / 80 \mathrm{mmHg}$ & $<130 / 80 \mathrm{mmHg}$ & $120-130 / 70-79 \mathrm{mmHg}^{\mathrm{f}}$ \\
\hline HFrEF & $<130 / 80 \mathrm{mmHg}$ & $<130 / 80 \mathrm{mmHg}$ & NA & $<130 / 80 \mathrm{mmHg}$ & NA \\
\hline
\end{tabular}

ACC American College of Cardiology, AHA American Heart Association, BP blood pressure, $C A D$ coronary artery disease, $C H L$ Chinese Hypertension League, $C K D$ chronic kidney disease, DM diabetes mellitus, ESC European Society of Cardiology, ESH European Society of Hypertension, HFrEF heart failure with reduced ejection fraction, JSH Japanese Society of Hypertension, KSH Korean Society of Hypertension, NA not available.

a $<130 / 80 \mathrm{mmHg}$, if tolerable or high risk

b $<140 / 90 \mathrm{mmHg}$, if tolerable

c $<130 / 80 \mathrm{mmHg}$, if high risk.

d $<130 / 80 \mathrm{mmHg}$, with lacunar infarction.

e $<140 / 90 \mathrm{mmHg}$ for bilateral cervical arteries stenosis, main cerebral artery occlusion or unevaluated.

f $130-139 / 70-79 \mathrm{mmHg}$ for people aged $\geq 65$ years.

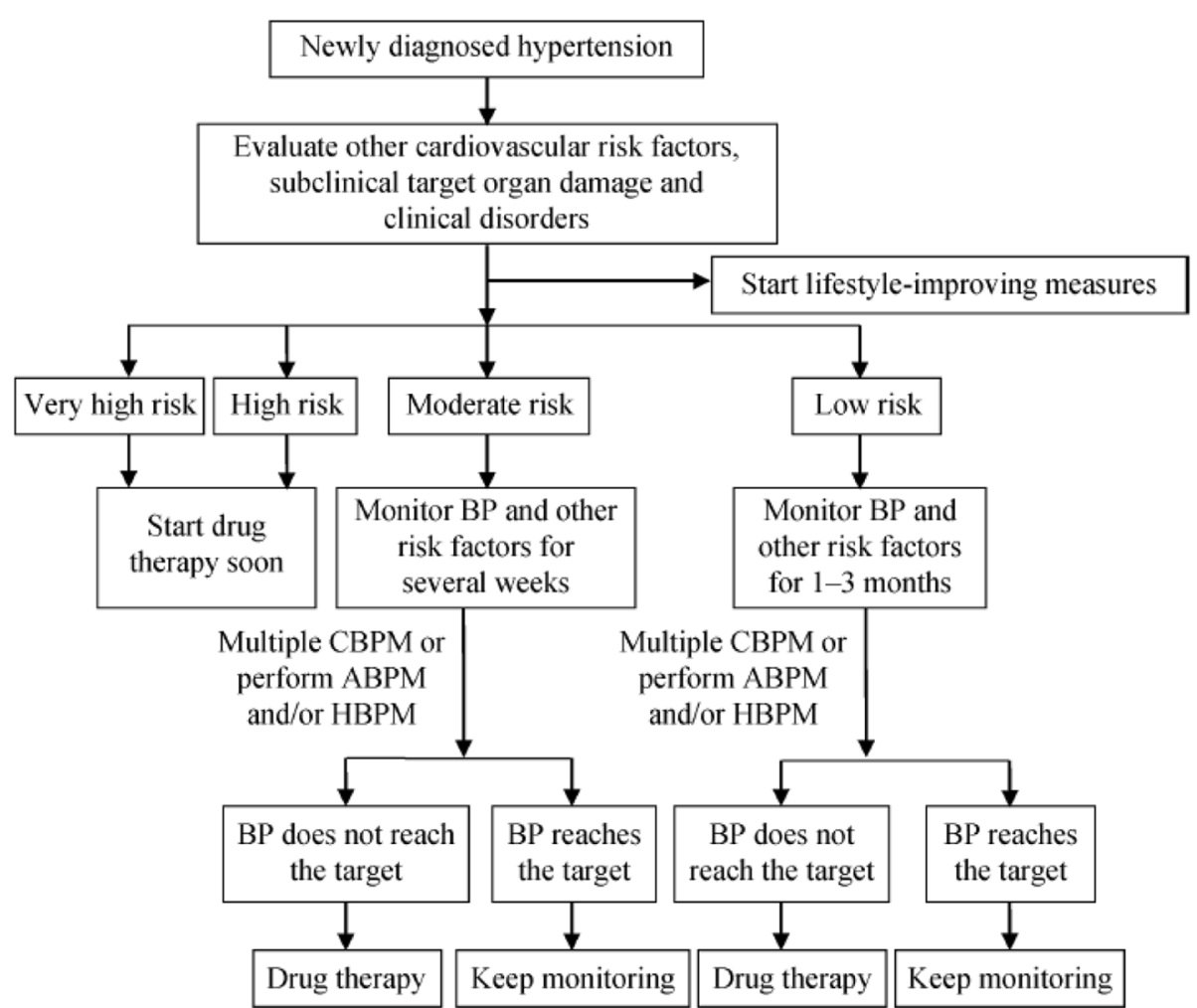

Fig. 1 Evaluation and monitoring procedures for newly diagnosed hypertension. Diagnostic criteria of hypertension for ABPM: daytime mean $\mathrm{SBP} \geq 135 \mathrm{mmHg}$ or DBP $\geq 85 \mathrm{mmHg}$, nighttime mean SBP $\geq 120 \mathrm{mmHg}$ or DBP $\geq 70 \mathrm{mmHg}$, or 24-h mean SBP $\geq 130 \mathrm{mmHg}$ or DBP $\geq 80 \mathrm{mmHg}$; Criteria for HBPM: mean SBP $\geq 135 \mathrm{mmHg}$ or DBP $\geq 85 \mathrm{mmHg}$. High risk patients with BP 130-139/85-89 mmHg or above, or moderate risk patients with $B P \geq 160 / 100 \mathrm{mmHg}$ should start drug therapy immediately. ABPM: ambulatory blood pressure monitoring; BP: blood pressure; CBPM: clinic blood pressure measurement; DBP: diastolic blood pressure; HBPM: home blood pressure monitoring; SBP: systolic blood pressure 


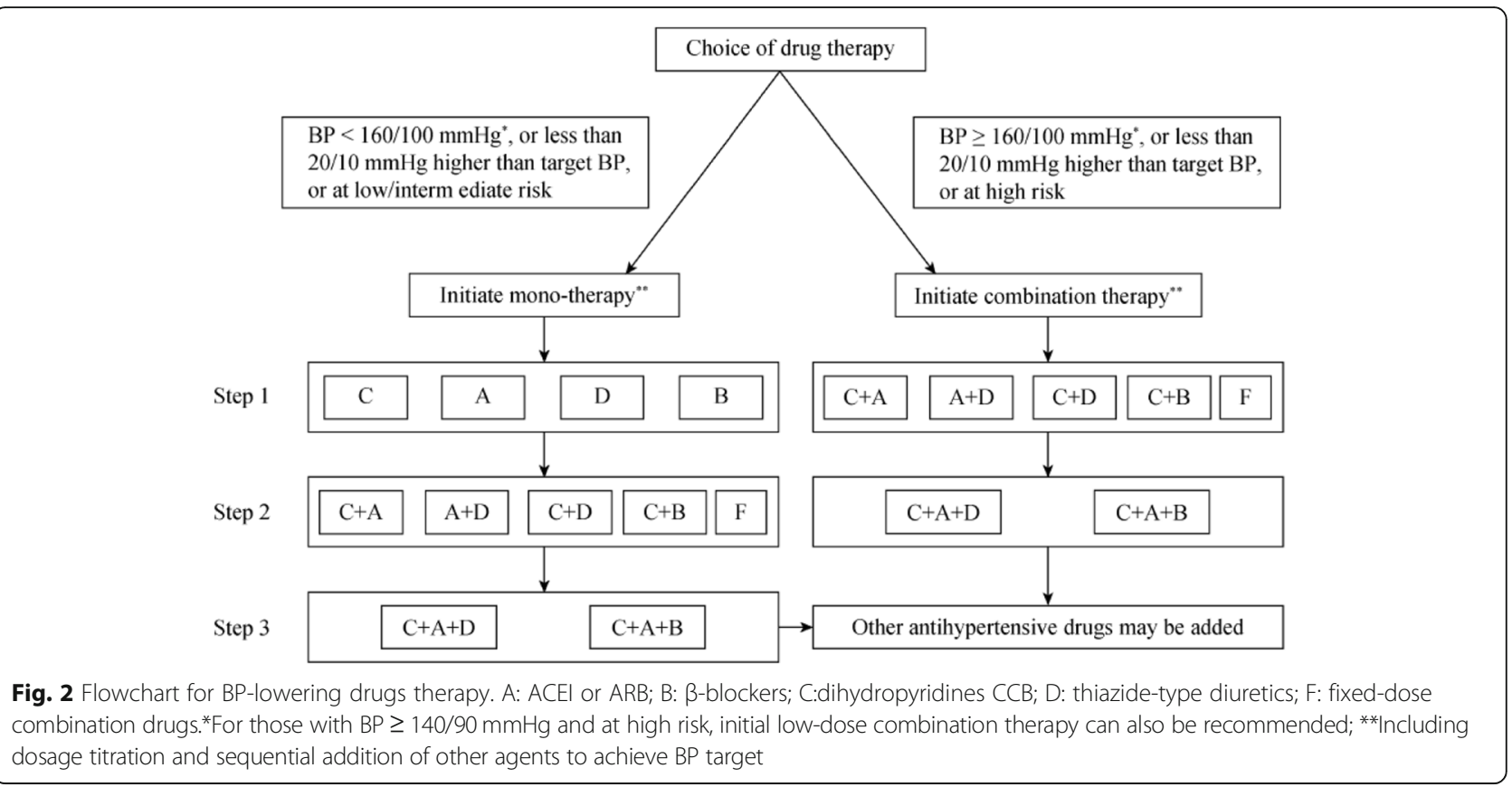

Systolic Pressure Intervention Trial (SPRINT) and metaanalysis uniformly demonstrated lower BP is better [13, 14]. If BP target not achieved, the dosage may be increased or combined with other antihypertensive agents. The 2018 Chinese hypertension guidelines provided a more flexible combination protocol, $\mathrm{ACEI} / \mathrm{ARB}+\mathrm{CCB}$ or diuretic, $\mathrm{CCB}+$ diuretic or $\mathrm{CCB}+\beta$-blocker were all preferred combination options. (Fig. 2).

Of note, lifestyle interventions are addressed at all stage of hypertension, and a strategy of comprehensive management of CV risks, including dyslipidemia, impaired glucose tolerance/diabetes or overweight and obesity is highly recommended.

\section{Conclusions}

China has never stopped exploring on the road of prevention and treatment of hypertension. Despite the fact that active and flexible healthcare policies have been made for publics, we have to face the great challenge in diminishing and eliminating the imbalance in economic development in eastern and western region of China. Guideline-recommended five classes of BP-lowering medications, especially long-acting preparations are not always available or affordable in primary care settings of different areas [15]. BP are uncontrolled currently in over $80 \%$ hypertensive population [5]. On the other hand, we have to face the rapid growing of prehypertension, hypertension and $\mathrm{CV}$ diseases in younger population in China [16]. There are unmet needs for providing healthcare professionals with a tailored hypertension management strategy in this special population. An expert consensus has been developed and published recently to meet the unmet needs [17].

Based on clinical evidence and expertise, the newest guidelines and consensus will be of help in guiding physicians and practitioners to provide better management of hypertension in China. But we should clearly recognize that there is still a long way to go before the satisfied BP control is achieved.

\section{Abbreviations}

ABPM: Ambulatory blood pressure monitoring; ACC: American College of Cardiology; ACEl: Angiotensin-converting enzyme inhibitor; AHA: American Heart Association; ARB: Angiotensin II receptor blocker; BP: Blood pressure; CAD: Coronary artery disease; CCB: Calcium channel blocker; CHL: Chinese Hypertension League; CKD: Chronic kidney disease; CSC: Chinese Society of Cardiology; CSPPT: Chinese Stroke Primary Prevention Trial;

CV: Cardiovascular; DBP: Diastolic blood pressure; DM: Diabetes mellitus; ESC: European Society of Cardiology; ESH: European Society of Hypertension; HBPM: Home blood pressure monitoring; HFrEF: Heart failure with reduced ejection fraction; ISH: Isolated systolic hypertension; JSH: Japanese Society of Hypertension; KSH: Korean Society of Hypertension; OBP: Office blood pressure.; NA: Not available; SBP: Systolic blood pressure; SPC: Single pill combination; SPRINT: Systolic Pressure Intervention Trial; TOD: Target organ damage; US: United States

\section{Acknowledgements}

The author expresses thanks to Ms. Xiaofeng Su for the literature preparations.

\section{Declarations}

This review is based on a presentation at Hypertension Seoul 2019.

\section{Author's contributions}

Jing Liu wrote the manuscript. The author has read and approved the final manuscript.

Funding

Not applicable. 
Availability of data and materials

Not applicable.

Ethics approval and consent to participate

Not applicable.

\section{Consent for publication}

Not applicable.

\section{Competing interests}

The author declares that he has no competing interests.

Received: 13 January 2020 Accepted: 13 March 2020

Published online: 01 May 2020

\section{References}

1. Joint Committee for guideline revision. 2018 Chinese guidelines for prevention and treatment of hypertension - a report of the revision committee of Chinese guidelines for prevention and treatment of hypertension. J Geriatr Cardiol. 2019;16(3):182-241.

2. Whelton PK, Carey RM, Aronow WS, et al. 2017 ACC/AHA/AAPA/ABC/ACPM/ AGS/APhA/ASH/ASPC/NMA/PCNA guidelines for the prevention, detection, evaluation, and Management of High Blood Pressure in adults: a report of the American College of Cardiology/American Heart Association task force on clinical practice Guideliness. Hypertension. 2018;71:e13-e115.

3. Williams B, Mancia G, Spiering W, et al. 2018 ESC/ESH guidelines for the management of arterial hypertension. Eur Heart J. 2018;39(33):3021-104.

4. Zhou M, Wang $H$, Zeng $X$, et al. Mortality, morbidity, and risk factors in China and its provinces, 1990-2017: a systematic analysis for the global burden of disease study 2017. Lancet. 2019;394:1145-58.

5. Wang Z, Chen Z, Zhang $L$, et al. Status of hypertension in China: results of China hypertension survey, 2012-2015. Circulation. 2018;137(22):2344-56.

6. Wang Z, Hao G, Wang $X$, et al. Clinical outcomes and economic impact of 2017 AHA/ACC guidelines on hypertension in China. J Clin Hypertens. 2019; 21(8):1212-20.

7. Kim H, Ihm S, Kim G, et al. 2018 Korean Society of Hypertension Guidelines for the management of hypertension: part l-epidemiology of hypertension. Clin Hypertens. 2019;25:16. https://doi.org/10.1186/s40885-019-0121-0.

8. Lee H, Shin J, Kim G, et al. 2018 Korean Society of Hypertension Guidelines for the management of hypertension: part II-diagnosis and treatment of hypertension. Clin Hypertens. 2019;25:20. https://doi.org/10.1186/s40885019-0124-x.

9. Kim K, Ihm S, Kim G, et al. 2018 Korean society of hypertension guidelines for the management of hypertension: part III-hypertension in special situations. Clin Hypertens. 2019;25:19. https://doi.org/10.1186/s40885-0190123-y.

10. Umemura S, Arima H, Arima S, et al. The Japanese Society of Hypertension Guidelines for the management of hypertension (JSH 2019). Hypertens Res. 2019;42:1235-481

11. Han L, Wu Q, Wang C, et al. Homocysteine, ischemic stroke, and coronary heart disease in hypertensive patients. A population-based, prospective cohort study. Stroke. 2015;46:1777-86

12. Huo Y, Li J, Qin X, et al. Efficacy of folic acid therapy in primary prevention of stroke among adults with hypertension in China: the CSPPT randomized clinical trial. JAMA. 2015;313(13):1325-35.

13. The SPRINT Research Group. A randomized trial of intensive versus standard blood-pressure control. N Engl J Med. 2015;373(22):2103-16.

14. Xie X, Atkins E, LV J, et al. Effects of intensive blood pressure lowering on cardiovascular and renal outcomes, updated sytemic review and metaanalysis. Lancet. 2016;387:435-43.

15. Su M, Zhang Q, Bai X, et al. Availability, cost, and prescription patterns of antihypertensive medications in primary health care in China: a nationwide cross-sectional survey. Lancet. 2017;390:2559-68.

16. Qi Y, Han X, Zhao D, et al. Long-term cardiovascular risk associated with stage 1 hypertension defined by the 2017 ACC/AHA hypertension quideline. J Am Coll Cardiol. 2018;72:1201-10.

17. Liu J, Lu X, Chen L, Huo Y. Expert consensus on the management of hypertension in the young and middle-aged Chinese population. Int J Clin Pract. 2019;73(12):e13426. https://doi.org/10.1111/ijcp.13426.

\section{Publisher's Note}

Springer Nature remains neutral with regard to jurisdictional claims in published maps and institutional affiliations.
Ready to submit your research? Choose BMC and benefit from:

- fast, convenient online submission

- thorough peer review by experienced researchers in your field

- rapid publication on acceptance

- support for research data, including large and complex data types

- gold Open Access which fosters wider collaboration and increased citations

- maximum visibility for your research: over $100 \mathrm{M}$ website views per year

At BMC, research is always in progress.

Learn more biomedcentral.com/submissions 